удк 640.43:338.48

\title{
ОЦІНКА ЕФЕКТИВНОСТІ ІННОВАЦІЙНОї ДІЯЛЬНОСТІ ПІДПРИЄМСТВ РЕСТОРАННОГО БІЗНЕСУ
}

\section{EVALUATION OF EFFICIENCY OF INNOVATIVE ACTIVITY OF RESTAURANT BUSINESS ENTERPRISES}

\author{
Постова Валентина Вікторівна \\ кандидат економічних наук, \\ Вінницький торговельно-економічний інститут \\ Київського національного торговельно-економічного університету \\ ORCID: https://orcid.org/0000-0002-0056-5648
}

Postova Valentyna

Vinnytsia Trade and Economic Institute of

Kyiv National University of Trade and Economics

\begin{abstract}
В статті наведено розрахунок ефективності інноваційної діяльності, який базується на праксеологічному підході, що передбачає взаємозв'язок цільового, системного та ресурсного підходів. Визначено, що обрані підприємством методичні підходи до оцінки інноваційних процесів визначають рівень есрективності її проведення. Наведено схему послідовності визначення рівня інноваційної активності підприємств ресторанного бізнесу. Обрання методики оцінювання доцільності інноваційних процесів у системі управління інноваційною діяльністю є важливим орієнтиром для підвищення ефективності стратегічного управління. Розроблено стадії комплексного оцінювання та аналізу інноваційної діяльності. Розроблено алгоритм оцінювання стану та результативності стратегічного управління інноваційною діяльністю на підприємстві ресторанного господарства. Наведено основні заходи для підвищення результативності від інноваційної діяльності.
\end{abstract}

Ключові слова: ресторанне господарство, інноваційна діяльність, праксеологічний підхід, інноваційна активність, стратегічні заходи, тактичні заходи, інноваційна активність.

В статье приведен расчет эффективности инновационной деятельности, основанный на праксеологическом подходе, который предусматривает взаимосвязь целевого, системного и ресурсного подходов. Определено, что выбранные предприятием методические подходы к оценке инновационных процессов определяют уровень эфффективности ее проведения. Приведена схема последовательности определения уровня инновационной активности предприятий ресторанного бизнеса. Избрание методики оценки целесообразности инновационных процессов в системе управления инновационной деятельностью является важным ориентиром для повышения эффективности стратегического управления. Разработаны стадии комплексной оценки и анализа инновационной деятельности. Разработан алгоритм оценки состояния и результативности стратегического управления инновационной деятельностью на предприятии ресторанного хозяйства. Приведены основные меры по повышению результативности от инновационной деятельности.

Ключевые слова: общественное питание, инновационная деятельность, праксеологический подход, инновационная активность, стратегические меры, тактические меры, инновационная активность.

The purpose of the article is to form theoretical and methodological principles and practical recommendations for assessing the effectiveness of strategic management of innovation in the restaurant industry, taking into account modern market requirements and the state of the domestic economy. The following scientific methods were used in the article: theoretical generalization, dialectical cognition - to determine the peculiarities of the interpretation of the concept of "innovation"; system analysis, synthesis, abstract-logical analysis - to determine methods for assessing the effectiveness of the system of strategic management of innovative development, generalization of research results; graphic analysis - for a visual representation of the findings of the study. The article presents the calculation of the effectiveness of innovation, which is based on a praxeological approach, which involves the relationship of target, system and resource approaches. It is determined that the methodological approaches chosen by the enterprise to the assessment of innovation processes determine the level of efficiency of its implementation. The scheme of sequence of definition of level of innovative activity of the enterprises of restaurant business is resulted. The choice of methods for assessing the feasibility of innovation processes in the management system of innovation is an import- 
ant guideline for improving the effectiveness of strategic management. Stages of complex evaluation and analysis of innovation activity are developed. An algorithm for assessing the status and effectiveness of strategic management of innovation at the restaurant business has been developed. The main measures to increase the effectiveness of innovation are presented. The obtained results of scientific research, conclusions, proposed algorithms, methodical recommendations, systems of indicators will support the entry of the system of strategic management of innovation in the general management system of restaurant enterprises, obtaining the planned effect from the implementation of innovative projects.

Keywords: restaurant economy, innovative activity, praxeological approach, innovative activity, strategic measures, tactical measures, innovative activity.

Постановка проблеми. Оцінка рівня ефрективності інноваційної діяльності підприємств ресторанного бізнесу визначається як фрункція менеджменту, цілеспрямована на опрацьовування фонансово-господарського стану, особливостей діяльності, аналізу інноваційних процесів та побудови, на засадах отриманої узагальненої інформації, висновків для прийняття вдалих управлінських рішень.

У цілях зростання прибутковості, ефективності господарювання в умовах розвиненого ринкового середовища та інноваційних технологій підприємства ресторанного господарства потребують особливого наукового новітнього підходу щодо стратегічного управління інноваційною діяльністю. Метою менеджменту у даному напрямі $€$ дослідження та застосування наукових теоретико-методичних положень у ссрері срормування вдалої інноваційної стратегії.

Аналіз останніх досліджень і публікацій. На даний час існує значна кількість праць щодо теоретичних та практичних аспектів ведення управління інноваційною діяльністю на підприємствах. Зокрема, вони стали предметом дослідження у працях вітчизняних вчених Я. Біленська [1], В. Гриньова, Д. Бутенко [2], П. Курмаєв, О. Матрос [3], С. Лихолет [6], Н. Рудь [8], Г. Черноіванова [9] та ін.

Виділення невирішених раніше частин загальної проблеми. Аналітичне дослідження теоретико-методологічних основ реалізації стратегічного управління інноваційною діяльністю показало, що за теперішніх умов не вирішеним залишаються питання особливостей розробки ефрективної системи стратегічного управління інноваційною діяльністю, орієнтованої на довгострокову перспективу. Відповідно, науковий та практичний інтерес досліджуваної тематики обумовлений необхідністю інноваційного розвитку та фрормування конкурентних переваг підприємств ресторанного господарства.

У зв'язку з вищевикладеним, постає необхідність визначення методів оцінки та фрормування стратегічного управління інноваційною діяльністю, в якій процес змін, розвитку економічного прогресу був закладений в основу системи фуннцціонування сучасного підприємства.

Формування цілей статті. Метою даної статті $\epsilon$ фрормування теоретико-методичних засад та практичних рекомендацій щодо оцінки есрективності стратегічного управління інноваційною діяльністю на підприємствах ресторанного господарства із врахуванням сучасних ринкових вимог та стану вітчизняної економіки.

Виклад основного матеріалу. Наукові погляди більшості авторів щодо критеріїв оцінки інноваційної діяльності ґрунтуються на визначенні ефективності шляхом співставлення ефекту (результату) використання інновацій та понесених витрат на інноваційний процес, виробництво інноваційної продукції. Тобто отримання додаткових доходів, які підприємство може залучати у інші ссрери діяльності для свого розвитку. Розрахунок ефрективності інноваційної діяльності має базуватись на праксеологічному підході, що передбачає взаємозв'язок цільового, системного та ресурсного підходів (рис. 1). Обрані підприємством методичні підходи до оцінки інноваційних процесів визначають рівень ефективності її проведення.

Отримана результативність від інноваційного управління виявляється у науковому, економічному, технологічному, екологічному та соціальному ефекті.

Управлінський персонал, під час оцінювання інноваційної діяльності, може визначати коефріцієнт ефективності власних капіталовкладень у інноваційні процеси (К кап.ін.), що показує частину отриманого доходу на одну гривню вкладеного, у інноваційні процеси, капіталу:

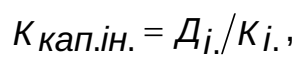

де $Д_{i .}$ - величина доходу від інноваційної діяльності;

$K_{i .}$ - величина капіталовкладень у інноваційні процеси [1, с. 218].

На етапі НДДКР має визначатись показник результативності (Рнддкр), срормула розрахунку якого має такий вигляд: 


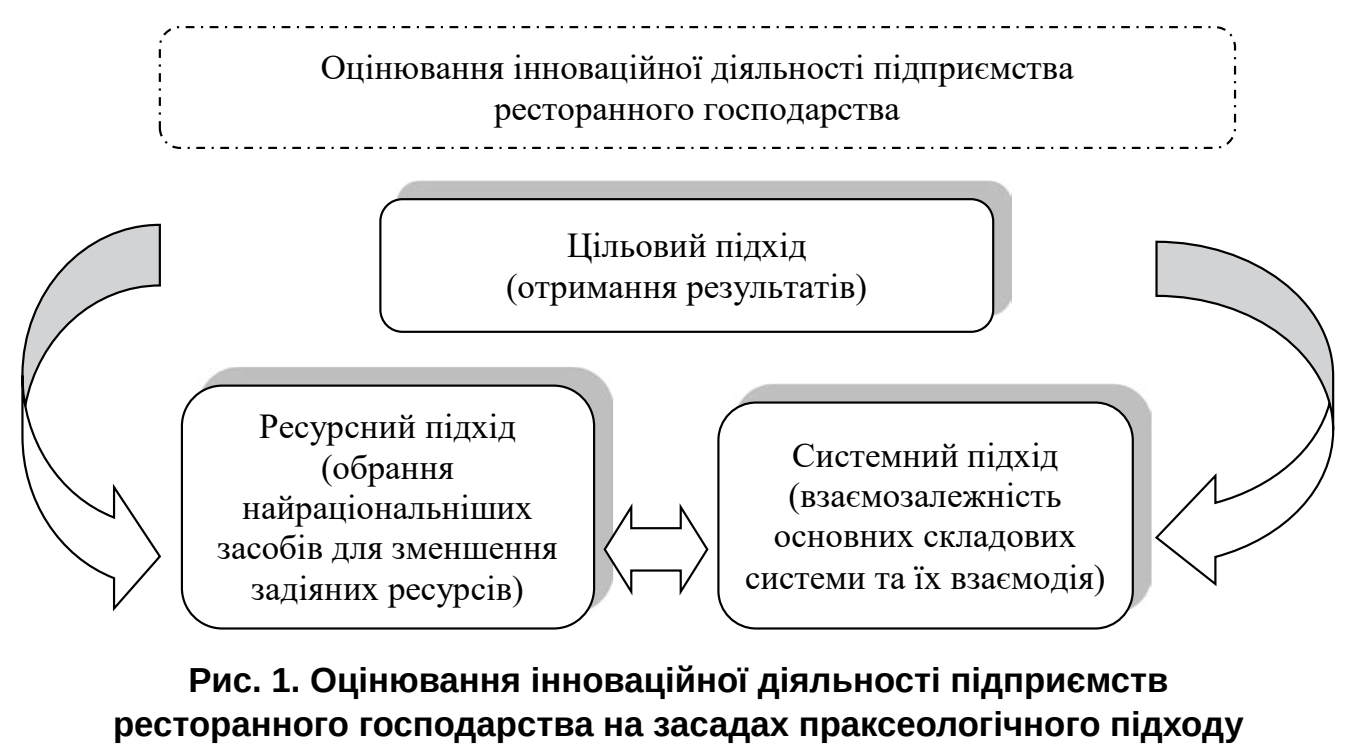

$P_{\text {ндакр }}=\left(N_{\text {eqp }}+N_{\text {пр.еqp. }}\right) /\left(N_{\text {зас. }}-N_{\text {реал. }}\right),(2)$

де $N$ еq. - кількість інновацій, розроблених власними силами, які $€$ економічно ефективними;

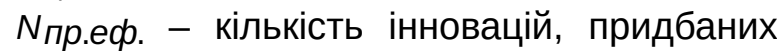
зі сторони із необхідним рівнем економічної есрективності;

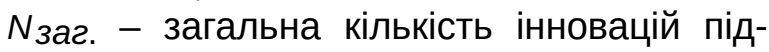
приємства внаслідок НДДКР та придбаних об'єктів інтелектуальної власності зі сторони;

$N$ реал. - загальна кількість інновацій підприємства внаслідок НДДКР та придбаних об'єктів інтелектуальної власності зі сторони, що були реалізовані на ринку [2].

у цілому проблема визначення ефективності і відбору найвигідніших варіантів реалізації інновацій потребує: по-перше, перевищення кінцевих результатів від їх використання над витратами на розроблення, виготовлення і реалізацію інновації; по-друге, зіставлення отриманих при цьому результатів 3 результатами від застосування інших аналогічних за призначенням варіантів інновацій. Особливо гостро постає необхідність швидкого оцінювання і правильного відбору варіанта інновації в закладах, які застосовують прискорену амортизацію, за якої строки заміни діючого обладнання на нове істотно скорочується. Крім того, метод оцінювання ефрективності інновацій залежить від об'єкта вимірювання ефективності. Об'єктом оцінювання ефрективності можуть виступати різні типи інновацій:

- засоби і знаряддя праці (нові, реконструйовані, модернізовані);

- предмети праці (сировина, паливо, матеріали, енергія);
- предмети кінцевого споживання;

- технологічні процеси;

- методи організації виробництва, праці та управління;

- інноваційний проект [3, с. 84].

Формуванню системи заходів, прийняття рішень із зростання інноваційного потенціалу та інноваційної активності підприємства ресторанного бізнесу передує оцінювання ії стану (рис. 2).

Головним чином оцінювання проводиться не відносно інноваційної діяльності в цілому, а конкретно інноваційного проекту. Обрання методики оцінювання доцільності інноваційних процесів у системі управління інноваційною діяльністю $є$ важливим орієнтиром для підвищення есрективності стратегічного управління.

На основі проведення теоретико-практичних досліджень щодо стану інноваційних процесів на підприємствах ресторанного господарства, узагальнення існуючих проблем, рівня потенціалу та інноваційної активності зроблено висновок, що для підвищення ефективності ффункціонування підприємств варто проводити комплексне оцінювання та аналіз інноваційної діяльності за рядом стадій (рис. 3).

Розглянемо порядок розрахунку ефрективності деяких об'єктів інновацій. Оцінювання інноваційної діяльності підприємств ресторанного господарства передбачає застосування загальних показників оцінки ефективності інноваційних процесів, зокрема:

- показники виробничої ефективності науково-технічних заходів: темпи приросту есрективності виробництва конкретних видів продукції (робіт) від використання науковотехнічних заходів; відносна економія собівар- 


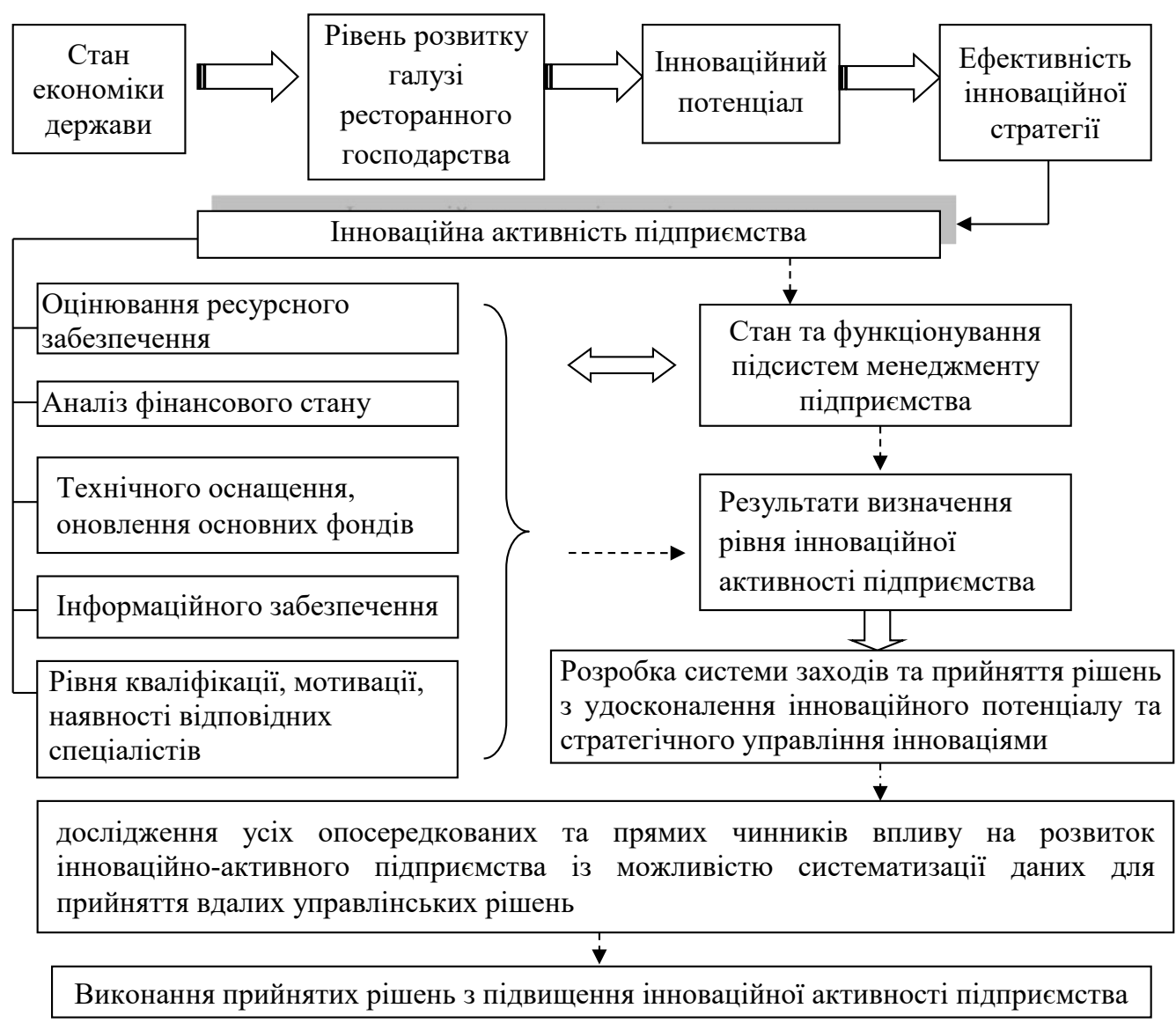

\section{Рис. 2. Схема послідовності визначення рівня інноваційної активності підприємств ресторанного бізнесу}

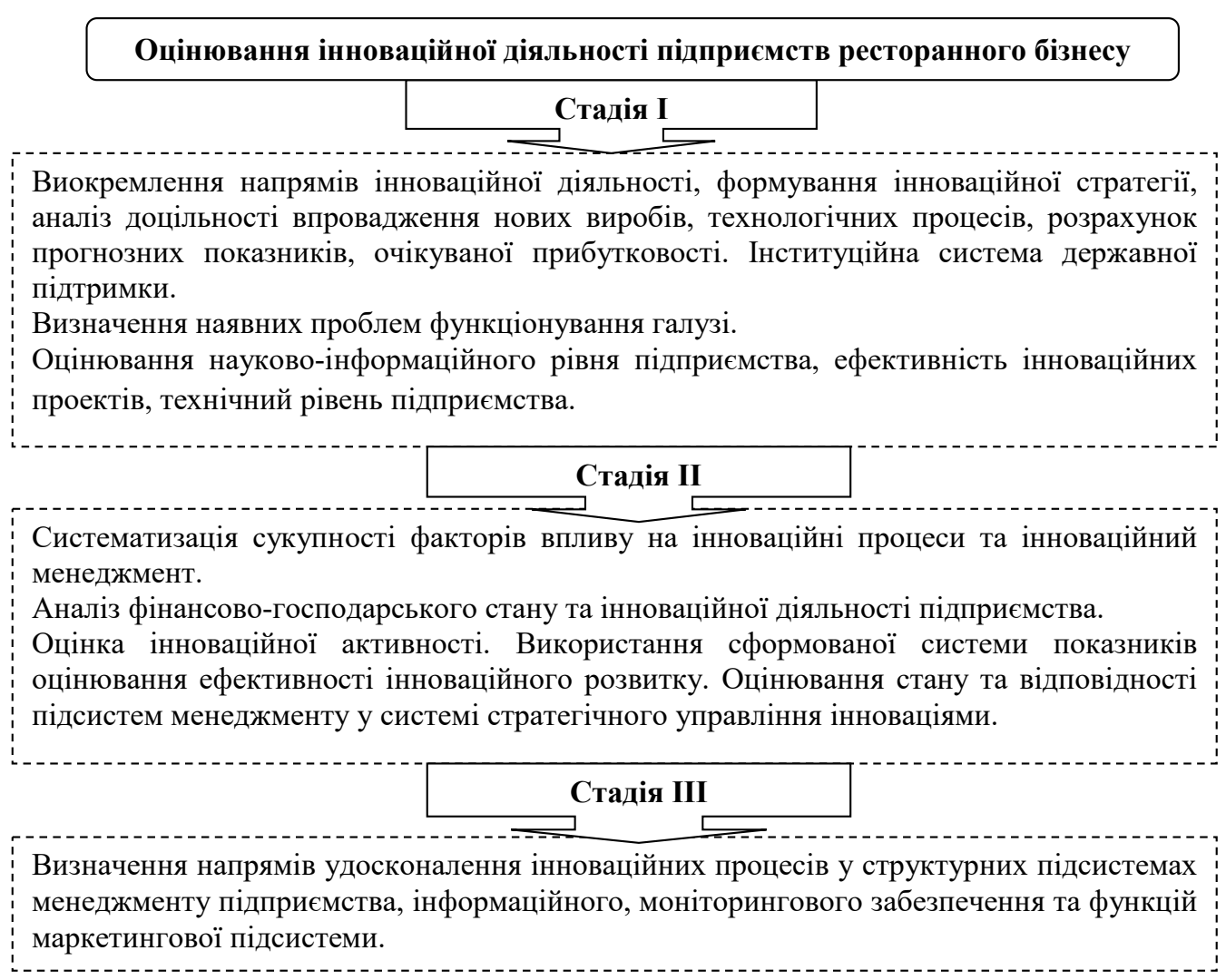

Рис. 3. Стадії комплексного оцінювання та аналізу інноваційної діяльності 
тості продукції в результаті запровадження науково-технічних заходів;

- показники фрінансової ефективності науково-технічних заходів: приріст прибутку в результаті реалізації науково-технічних заходів; приріст доданої вартості, включаючи амортизацію, в результаті реалізації науковотехнічних заходів, у тому числі за рахунок інтенсивних і екстенсивних фракторів; приріст доходу за рахунок реалізації науково-технічних заходів;

- показники інвестиційної ефективності науково-технічних заходів: ці показники характеризують кількість впроваджених науково-технічних засобів, зростання питомої ваги прогресивних технологічних процесів та нових інформаційних технологій, підвищення коефріцієнта автоматизації та організаційного рівня виробництва і праці, підвищення конкурентоспроможності підприємства, товарів та послуг на ринку [4, с. 183].

У підсистемі оцінки та ефрективності застосування системи стратегічного управління інноваційним розвитком підприємств варто виокремити критерії оцінювання ефективності інноваційного проекту у розрізі двох аспектів: кількісне визначення рівня отримання поставленої мети від реалізації інноваційного проекту та врахування критерію як основи для відбору найоптимальнішого управлінського рішення. Менеджерами можуть застосовуватись ряд параметрів, що показуватимуть виконання принципів формування системи, 3 метою оцінювання результативності якої визначається окремий критерій:

- рівень ефективності окремого стратегічного рішення відносно інноваційних проектів, наприклад показник чистого приведеного есректу, рентабельності, терміну окупності тощо;

- обсяг та розподілення за визначеними періодами інвестованих фрінансових ресурсів;

- оцінювання періоду виконання управлінського рішення у стратегічній інноваційній діяльності та ризиків інноваційного проекту;

- існуючі обмеження у виробничому процесі, визначення наявності відповідних спеціалістів для впровадження інновацій;

- оцінювання ліквідності, а саме рух фрінансових ресурсів, застосовуваних основних засобів.

Дані визначених параметрів оцінювання можна отримати у детермінованому чи стохастичному виді потенційних прогнозів діяльності. Такі дії дають змогу скоригувати стратегічні рішення щодо інноваційного процесу. Аналіз інноваційної діяльності підприємства ресторанного бізнесу загалом проводиться на основі даних статистичного аналізу, але на думку деяких науковців не у повній мірі відображає едективність інноваційних процесів. Тому підсистему оцінювання інноваційної діяльності варто доповнювати додатковими показниками. Але, в той же час, це вимагає повноцінного інформаційного забезпечення менеджерів [5, с. 23].

Інтегральний показник рівня інноваційного розвитку підприємства ресторанного господарства формується на базі комплексного показника інноваційної активності та інноваційної сприйнятливості підприємства. До першого відносять кількість освоєних (впроваджених) нових видів продукції, частку впроваджених нових технологічних процесів, частку реалізованої інноваційної продукції, коефріцієнт використання витрат на інноваційні процеси, коефріцієнти рентабельності інновацій, частку виготовлених інновацій, які $€$ новими на ринку та окремо новими для підприємства, частку інноваційної продукції, спрямованої на експорт у загальній величині виготовлених інновацій, коефріцієнти фрінансової стійкості та покриття.

Комплексна система показників аналізу та оцінювання інноваційної діяльності підприємств ресторанного господарства, що надаватиме можливість проводити аналіз по сракторам, включає такі основні групи показників: оцінювання ефективності інноваційних рішень, показники ліквідності, срінансової стійкості, платоспроможності, показники оцінки ділової активності, ефективності діяльності та використання ресурсів (рис. 4).

При оцінюванні рівня ефективності інноваційних проектів на підприємстві важливим $€$ проведення:

ᄀ- оцінки впливу на фрінансово-господарську діяльність впровадження інновацій;

- моделювання розгалуження ресурсів для інноваційних процесів;

- аналізу впливу інноваційно-інвестиційних проектів підприємства на зовнішнє середовище;

- оцінки есрективності із врахуванням впливу інфрляційних процесів;

- визначення ефректу від співставлення отримуваних результатів інноваційної діяльності та, понесених на інноваційні проекти, витрат;

- аналізу можливих ризиків та невизначеностей відносно впровадження інновацій [6, с. 11].

Визначено, що основним завданням підсистеми оцінювання ефрективності іннова- 
Система показників аналізу та оцінювання інноваційної діяльності

Показники оцінки ефективності інноваційних рішень

Чистий дисконтований дохід, внутрішня норма прибутковості, рентабельність інвестицій в інноваційний проект, дисконтований період окупності інноваційного проекту, чиста приведена економія; економічна додана вартість, період окупності інвестицій, ефективність проекту; оцінювання конкурентоспроможності, ризикованості інноваційних рішень, прогнозування результатів здійснення інноваційних проектів.

\begin{tabular}{|l} 
Показники ліквідності, фінансової стійкості та платоспроможності \\
Коефіцієнти поточної, швидкої, абсолютної ліквідності; коефіцієнти автономії \\
(незалежності), заборгованості, концентрації залученого капіталу, поточної \\
заборгованості, довгострокової фінансової незалежності, здатності до маневрування \\
власних засобів, маневреності власного та позичкового капіталів, коефіцієнти \\
платоспроможності: абсолютної платоспроможності (ліквідності) підприємства, \\
поточної платоспроможності (швидкої ліквідності) підприємства, коефіцієнт покриття.
\end{tabular}

Показники оцінки ділової активності, ефективності діяльності та використання ресурсів

Коефіцієнт оборотності активів, оборотності оборотних активів, оборотності виробничих запасів, оборотності дебіторської заборгованості i кредиторської заборгованості, оборотності власного капіталу; валовий прибуток (збиток), прибуток (збитки) від операційної діяльності, прибуток (збиток) від фінансової діяльності, чистий прибуток (збиток), рентабельність капіталу активів, валова i чиста рентабельність реалізованої продукції, валова і чиста рентабельність виробництва; реалізована продукція чи послуги (обсяг продаж), рентабельність реалізованої продукції чи послуг, коефіцієнт конкурентоздатності; показники оцінювання ступеня ефективності використання матеріально-сировинної бази; показники для аналізу стану ефективності використання основних засобів, рівня використання трудових ресурсів та фонду оплати праці, показники якості.

Рис. 4. Комплексна система фундаментальних показників аналізу та оцінювання інноваційної діяльності підприємств ресторанного господарства

ційної діяльності підприємств ресторанного господарства має бути узагальнений аналіз результативності від впровадження інноваційних проектів, рівня їх сприяння у зміні основних (базових) показників господарювання, фрормулювання доцільності та обрання якнайкращих альтернатив здійснення інновацій, вчасне та продуктивне внесення змін (поправок) у інноваційний проект та у розроблену інноваційну стратегію.

Від дієвості даної підсистеми оцінювання інновацій та рівня відповідності її до процесів у загальному менеджменті підприємства залежатиме можливість вчасного внесення корективів у роботу окремих підрозділів у організаційній структурі інноваційного підприємства.

Аналіз рівня ефективності інноваційної діяльності підприємства доцільно проводити керуючись такими принципами як: принцип діалектики; принцип ранжирування; принцип єдності аналізу та синтезу; принцип оперативності; принцип забезпечення співвідношення можливих варіантів; принцип кількісної визначеності [7, с. 105].

Оцінювання стану та результативності стратегічного управління інноваційною діяльністю на підприємстві ресторанного господарства можна проводити за запропонованим алгоритмом (рис. 5).

Оцінювання ефективності інноваційних процесів можна розраховувати шляхом застосування інтегрального показника ступеня власного інноваційного розвитку підприємства. У свою чергу даний показник передбачає визначення:

- ресурсного забезпечення, що оцінюється через розрахунок показників рівня інноваційного потенціалу підприємства - рівня використання 


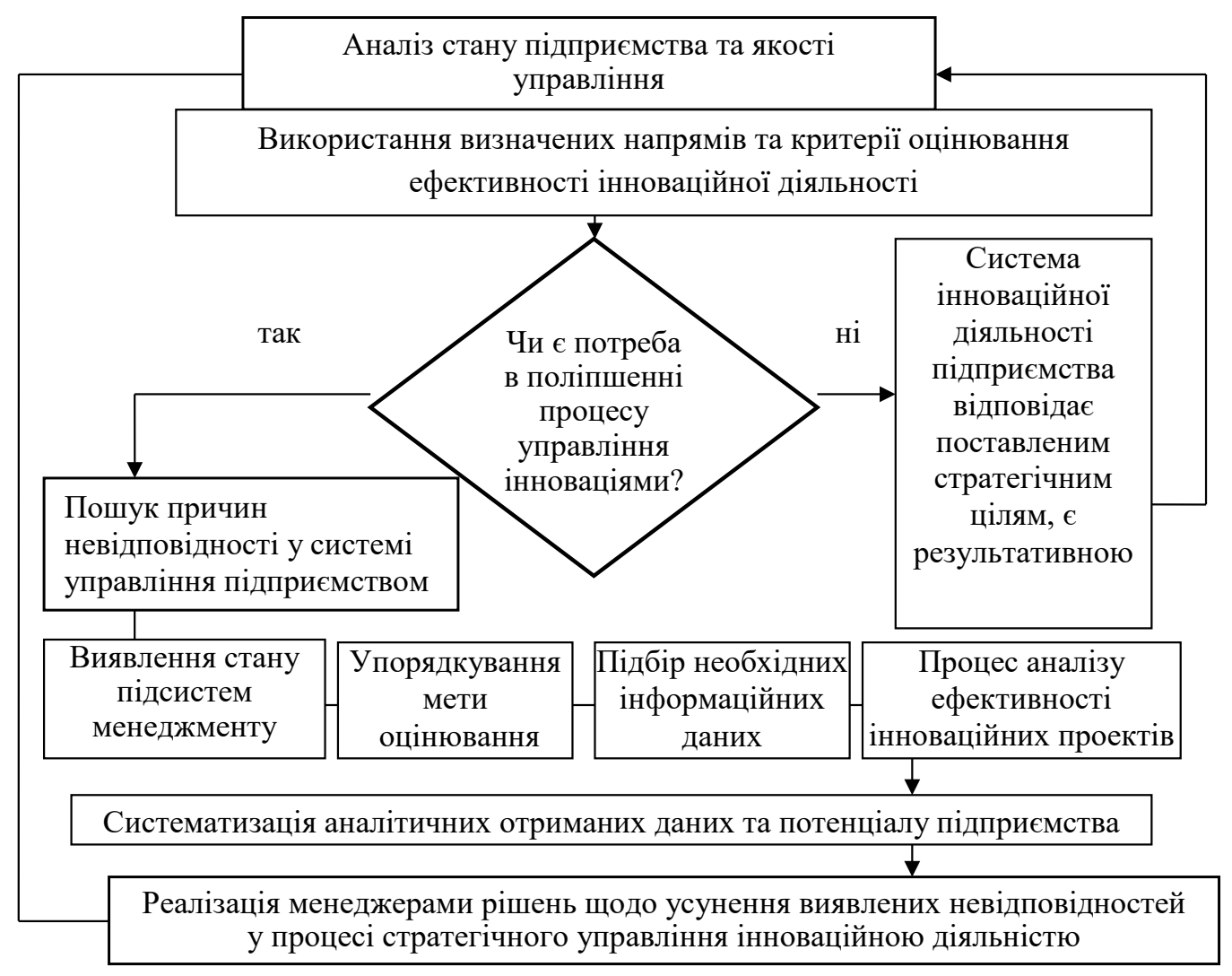

Рис. 5. Алгоритм оцінювання стану та результативності стратегічного управління інноваційною діяльністю на підприємстві ресторанного господарства

фрінансових ресурсів, наукового, матеріального, технічного, інфрормаційного та кадрового потенціалу господарюючого суб'єкта;

- технологічного забезпечення, яке менеджери можуть визначити через розрахунок показників технологічного оновлення - показники ефрективності використання основних засобів та технологій, устаткування (оснащення), продуктивності праці;

- ринкової складової, що визначається результативністю основних показників інноваційного підприємства - показники рентабельності збуту інновацій, ринкової віддачі активів, зайнятого підприємством сегменту ринку, пробних продажів інноваційних продуктів, споживчою задоволеністю від інновації, результативності проведення реклами, ритмічності реалізації новацій [8, с. 326].

На рівні стратегічного, тактичного, оперативного управління на підприємстві повинні проводитись заходи спрямовані на підвищення результативності від інноваційної діяльності та управління інноваційним розвитком (рис. 6).

Дієвість підсистеми оцінки та ефрективності застосування системи стратегічного управління інноваційним розвитком підприємств ресторан- ного бізнесу особлива важлива при побудові інноваційної стратегії - формування цілей розвитку на визначений термін. До головних внутрішніх фракторів, що аналізуються насамперед варто віднести оцінювання існуючого економічного потенціалу підприємства [8, с. 261].

Оцінку економічних результатів підприємств ресторанного господарства, при розбіжних величинах власного та позикового капіталів, можна проводити із застосуванням показника фрінансового левериджу, за допомогою якого визначають есрект, що існує у зростанні рівня рентабельності власного капіталу, через зміну частки позикового капіталу у сукупній вартості капіталу.

Результативність системи стратегічного управління інноваційною діяльністю підприємств ресторанної галузі визначається, поміж розглянутих вище фракторів, також входженням у цілісну систему менеджменту із фрормуванням на базі взаємозалежності, тісних взаємозв'язків їх структурних частин.

Висновки. На основі розглянутих науковометодичних поглядів щодо проведення оцінки інноваційної діяльності підприємств ресторанного господарства та узагальнення відповідних показників можна зробити висновок, що 


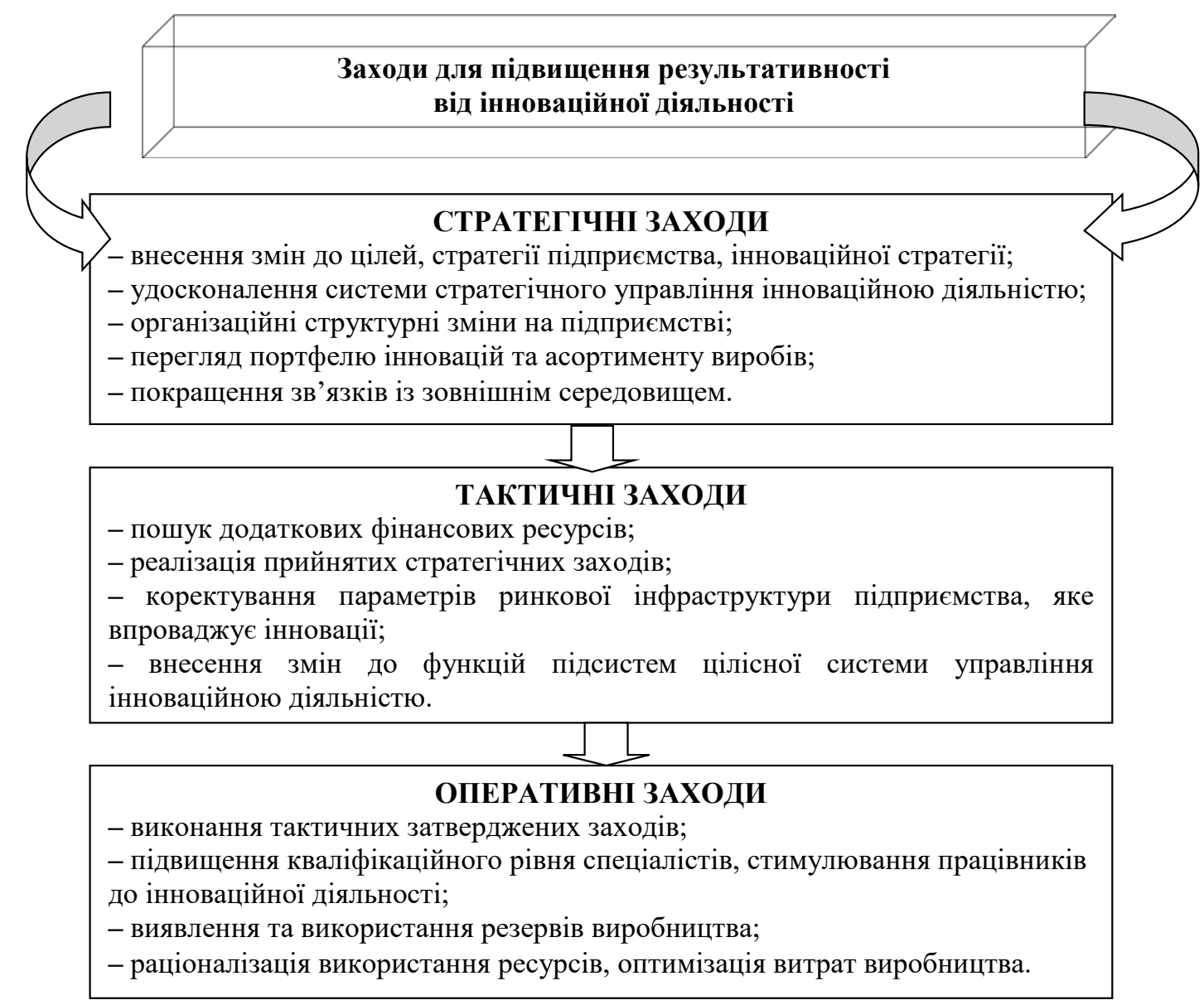

Рис. 6. Основні заходи для підвищення результативності від інноваційної діяльності

сприяти інноваційному розвитку можна шляхом модернізації основних засобів, технологічного забезпечення. Ці фрактори є підґрунтям зростання виготовлення та реалізації інновацій, умовою забезпечення конкурентоспроможності продукції та послуг галузі ресторанного бізнесу.
Наступним важливим фрактором розвитку й активізації інноваційних процесів є орормування та впровадження механізму оптимізації витрат, впровадженням ресурсозберігаючих технологій, залучення інвестиційних ресурсів для розробки й впровадження інновацій.

\section{СПИСОК ВИКОРИСТАНИХ ДЖЕРЕЛ:}

1. Біленська Я. Р. Використання збалансованої системи показників для оцінювання потенціалу інноваційного розвитку виробничо-господарського об'єднання. Бізнес Інфрорм, 2014, 1, 216-221.

2. Гриньова В.М., Бутенко Д.С. Оцінка результативності інноваційної діяльності підприємства : монограсрія. Харків : Вид. ХНЕУ, 2013.

3. Завальнюк В. В. Методика проектування підсистеми інформаційного забезпечення стратегічного управління інноваційною діяльністю підприємства. Науковий вісник Ужгородського національного університету. Серія : Міжнародні економічні відносини та світове господарство, 2016, 8(1), 82-85.

4. Завальнюк В. В. Принципи управління інноваційною діяльністю. Вісник Хмельницького національного університету. Економічні науки, 2013, 5(1), 182-185.

5. Курмаєв П.Ю., Матрос О.М. Аналіз інноваційної діяльності підприємств та її обліково-аналітичне забезпечення. Економіка. Фінанси. Право, 2015, 10, 21-24.

6. Лихолет С. І. Сучасні підходи оцінки ефективності економічного стимулювання інноваційної діяльності промислових підприємств. Інвестиції: практика та досвід, 2016, 1, 9-14.

7. Левицька І.В., Постова В. В. Основні поняття та значення підвищення економічної ефрективності інноваційної діяльності підприємств машинобудування. Економічний вісник Запорізької державної інженерної академії, 4(04), 1, 103-108. Запоріжжя, 2016. 
8. Рудь Н. Т. Нові методичні підходи до аналізу інноваційного потенціалу підприємства. Економічний форум, 2015, 3, 323-332.

9. Черноіванова Г. С. Показники есрективності інноваційних проектів. Вісник економіки транспорту і промисловості, 2012, 37, 260-263.

\section{REFERENCES:}

1. Bilenska, Ya. (2014). Vykorystannia zbalansovanoi systemy pokaznykiv dlia otsiniuvannia potentsialu innovatsiinoho rozvytku vyrobnycho-hospodarskoho obiednannia. Biznes Inform, 1, 216-221. (in Ukrainian)

2. Hrynova, V., Butenko D. (2013). Otsinka rezultatyvnosti innovatsiinoi diialnosti pidpryiemstva: monohrafiia. Kharkiv: Vyd. KhNEU. (in Ukrainian)

3. Zavalniuk, V. (2016). Metodyka proektuvannia pidsystemy informatsiinoho zabezpechennia stratehichnoho upravlinnia innovatsiinoiu diialnistiu pidpryiemstva. Naukovyi visnyk Uzhhorodskoho natsionalnoho universytetu. Seriia: Mizhnarodni ekonomichni vidnosyny ta svitove hospodarstvo, 8(1), 82-85. (in Ukrainian)

4. Zavalniuk, V. (2013). Pryntsypy upravlinnia innovatsiinoiu diialnistiu. Visnyk Khmelnytskoho natsionalnoho universytetu. Ekonomichni nauky, 5(1), 182-185. (in Ukrainian)

5. Kurmaiev, P., Matros, O. (2015). Analiz innovatsiinoi diialnosti pidpryiemstv ta yii oblikovo-analitychne zabezpechennia. Ekonomika. Finansy. Pravo, 10, 21-24. (in Ukrainian)

6. Lykholet, S. (2016). Suchasni pidkhody otsinky efektyvnosti ekonomichnoho stymuliuvannia innovatsiinoi diialnosti promyslovykh pidpryiemstv. Investytsii: praktyka ta dosvid, 1, 9-14. (in Ukrainian)

7. Levytska, I., Postova, V. (2016). Osnovni poniattia ta znachennia pidvyshchennia ekonomichnoi efektyvnosti innovatsiinoi diialnosti pidpryiemstv mashynobuduvannia. Ekonomichnyi visnyk Zaporizkoi derzhavnoi inzhenernoi akademii. Zaporizhzhia, 4(04), 1, 103-108. (in Ukrainian)

8. Rud, N. (2015). Novi metodychni pidkhody do analizu innovatsiinoho potentsialu pidpryiemstva. Ekonomichnyi forum, 3, 323-332. (in Ukrainian)

9. Chernoivanova, H. (2012). Pokaznyky efektyvnosti innovatsiinykh proektiv. Visnyk ekonomiky transportu $i$ promyslovosti, 37, 260-263. (in Ukrainian) 